\title{
Performance Improvement of Dye-Sensitized Solar Cell by Phenanthrothiadiazole Unit-Based $\pi$-Conjugated Bridge
}

\author{
Xiaoqiang Yu*, Yi Wang, Tianyu Huang, Zhenhua Ci, Ming Bao \\ State Key Laboratory of Fine Chemicals, Dalian University of Technology, Dalian, China \\ Email: *yuxiaoqiang@dlut.edu.cn
}

How to cite this paper: Yu, X.Q., Wang, Y., Huang, T.Y., Ci, Z.H. and Bao, M. (2018) Performance Improvement of DyeSensitized Solar Cell by Phenanthrothiadiazole Unit-Based $\pi$-Conjugated Bridge. Journal of Materials Science and Chemical Engineering, 6, 25-34. https://doi.org/10.4236/msce.2018.67004

Received: May 7, 2018

Accepted: July 1, 2018

Published: July 4, 2018

\begin{abstract}
New organic dyes (D1, D2, and D3) containing a phenanthrothiadiazole unit as a $\pi$-conjugated system, a triarylamine as an electron donor, and a cyanoacrylic acid moiety as an electron acceptor were synthesized. The optical and electrochemical properties of dyes D1, D2, and D3 were investigated, and their performance as sensitizers in solar cells was evaluated. Dye-sensitized solar cells based on dye D3 produced a photon-to-current conversion efficiency of $5.23 \%\left(\mathrm{Jc}=9.70 \mathrm{~mA} / \mathrm{cm}^{2}, V o c=0.77 \mathrm{~V}\right.$, ff 0.70$)$ under 100 $\mathrm{mW} / \mathrm{cm}^{2}$ simulated AM $1.5 \mathrm{G}$ solar irradiation.
\end{abstract}

\section{Keywords}

Organic Dye, Phenanthrothiadiazole, Dye-Sensitized Solar Cells, Efficiency

\section{Introduction}

Dye-sensitized solar cells (DSSCs) have attracted significant attention in recent years due to their high efficiency, low cost, and facile fabrication [1]. The sensitizer is one of the key components in these cells for high power conversion efficiency. Attention has recently focused on metal-free organic sensitizers (D- $\pi-A$ moleculars) because they present many advantages, such as high molar extinction coefficients, low cost, simple preparation process, and environment friendliness [2] [3] [4] [5]. D- $\pi$-A dyes based on triphenylamine moieties with various $\pi$-conjugated bridges, such as thiophene [6] [7] [8] [9], benzene [10]-[15], Coumarin [16], thienothiophene[17] [18] [19], benzo[b]thiophene [20] [21], phenothiazine [22], or dibenzosilole [23], have been developed for DSSCs to achieve high conversion efficiencies. The $\pi$-conjugated bridge has a great influence on photoelectronic properities of the $\mathrm{D}-\pi-\mathrm{A}$ dyes. 
This study presents three new organic dyes (D1, D2, and D3) with phenanthrothiadiazole unit as a $\pi$-conjugated bridge, different arylamine moieties as electron donors, and a cyanoacetic acid as electron acceptor (Figure 1). The study also investigates the photophysical, electrochemical, and photovoltaic properties.

\section{Experimental}

\subsection{General Analytical Measurements}

All chemicals were used as received from commercial sources without purification. Solvents for chemical synthesis, including toluene, dichloromethane (DCM), $\mathrm{MeOH}$ and tetrahydrofuran (THF), were purified by distillation. High-resolution mass spectra were recorded on either a Q-TOF or a GC-TOF mass spectrometer. ${ }^{1} \mathrm{H}$ and ${ }^{13} \mathrm{C}$ NMR spectra were recorded on either a Varian Inova-400 spectrometer $\left(400 \mathrm{MHz}\right.$ for ${ }^{1} \mathrm{H} ; 100 \mathrm{MHz}$ for ${ }^{13} \mathrm{C}$ ) or a Bruker Avance II-400 spectrometer (400 MHz for ${ }^{1} \mathrm{H} ; 100 \mathrm{MHz}$ for ${ }^{13} \mathrm{C}$ ).

\subsection{Fabrication of DSSCs}

A screen-printing technique was used to fabricate the $\mathrm{TiO}_{2}$ films. First, the paste was deposited on a fluorine-doped tin oxide conductive glass (FTO, Asahi Glass Co., Ltd.; sheet resistance: $10 \mathrm{ohm} / \mathrm{sq}$ ). The film was then sintered at $450^{\circ} \mathrm{C}$ for $30 \mathrm{~min}$ in atmospheric air, immersed in $40 \mathrm{mM} \mathrm{TiCl}_{4}$ solution for $30 \mathrm{~min}$ at $70^{\circ} \mathrm{C}$, rinsed with water and ethanol, and sintered at $500^{\circ} \mathrm{C}$ for $30 \mathrm{~min}$. The film was dipped into D1, D2, and D3 dye solutions ( $0.6 \mathrm{mM}$ in THF) for $18 \mathrm{~h}$ after cooling to $80^{\circ} \mathrm{C}$. Finally, dye-sensitized $\mathrm{TiO}_{2}$ photoelectrodes (thickness: $12 \mu \mathrm{m}$ ) were obtained. The organic electrolyte was composed of $0.06 \mathrm{M} \mathrm{LiI}, 0.03 \mathrm{M} \mathrm{I}_{2}$, $0.1 \mathrm{M}$ guanidinium thiocyanate, $0.6 \mathrm{M}$ 1-propyl-3-methylimidazolium iodide (PMII), and $0.5 \mathrm{M} t$-butyl-pyridine in acetonitrile. The active area of the DSSCs was $0.36 \mathrm{~cm}^{2}$. DSSCs devices were assembled with counter electrodes (thermally platinized FTO) using a thermoplastic frame (Surlyn, thickness: $60 \mu \mathrm{m}$ ).

\subsection{Measurements}

Absorption and emission spectra were respectively recorded by HP8453 (USA) and PTI700 (USA) instruments. Electrochemical measurements were carried out

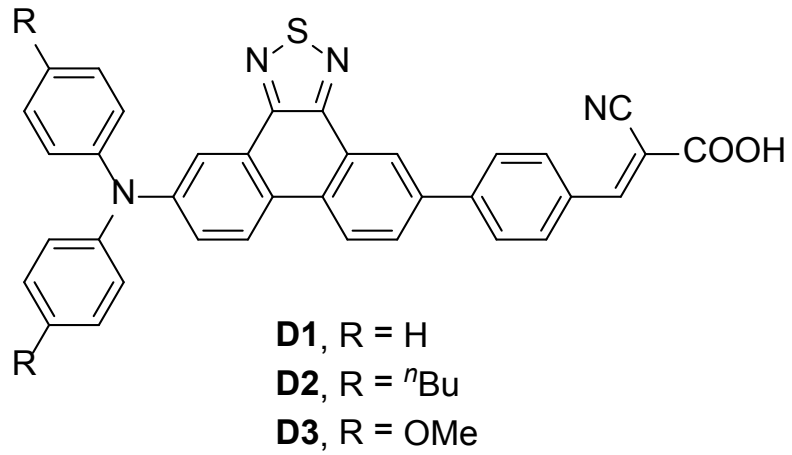

Figure 1. Molecular structures of dyes D1, D2, and D3. 
on a BAS100W (USA) electrochemistry workstation. The irradiation source for photocurrent-voltage (J-V) measurements was an AM 1.5 solar simulator (16S-002, Solar Light Co.Ltd., USA). The incident light intensity was 100 $\mathrm{mW} / \mathrm{cm}^{-2}$ and calibrated against a standard silicon solar cell. The J-V curve was obtained by the linear sweep voltammetry (LSV) method using an electrochemical workstation (LK9805, Lanlike Co. Ltd., China). Incident photon-to-current conversion efficiency (IPCE) measurements were performed on a Hypermonolight instrument (SM-25, Jasco Co. Ltd., Japan).

\section{Results and Discussion}

\subsection{Synthesis}

Dyes D1, D2, and D3 were synthesized following the steps depicted in Scheme 1.

3-1, (yellow solid, 53\% yield), mp $167^{\circ} \mathrm{C}-168^{\circ} \mathrm{C} .{ }^{1} \mathrm{H}$ NMR (400 $\mathrm{MHz}, \mathrm{CDCl}_{3}$ ) $\delta 9.02(\mathrm{~s}, 1 \mathrm{H}), 8.31-8.27(\mathrm{~m}, 2 \mathrm{H}), 8.09(\mathrm{~d}, J=8.4 \mathrm{~Hz}, 1 \mathrm{H}), 7.97(\mathrm{dd}, J=8.8,1.7$ $\mathrm{Hz}, 1 \mathrm{H}), 7.43(\mathrm{dd}, J=8.8,2.4 \mathrm{~Hz}, 1 \mathrm{H}), 7.35-7.31(\mathrm{~m}, 4 \mathrm{H}), 7.21(\mathrm{~d}, J=8.0 \mathrm{~Hz}$, $4 \mathrm{H}), 7.13(\mathrm{~d}, J=7.2 \mathrm{~Hz}, 2 \mathrm{H}) .{ }^{13} \mathrm{C} \mathrm{NMR}\left(100 \mathrm{MHz}, \mathrm{CDCl}_{3}\right) \delta 153.1,152.2,148.3$, $147.1,138.3,134.7,130.9,129.6,127.4,126.7,125.2,124.6,124.5,124.4,124.1$, 117.7, 92.3. HRMS (EI, m/z): calcd. for $\mathrm{C}_{26} \mathrm{H}_{16} \mathrm{~N}_{3} \mathrm{SI}$, 529.0110 [M]; found, 529.0107.

3-2, (yellow solid, $62 \%$ yield), mp $154^{\circ} \mathrm{C}-155^{\circ} \mathrm{C} .{ }^{1} \mathrm{H} \mathrm{NMR}\left(400 \mathrm{MHz}, \mathrm{CDCl}_{3}\right.$ ) $\delta 9.00(\mathrm{~d}, J=2.0 \mathrm{~Hz}, 1 \mathrm{H}), 8.25-8.22(\mathrm{~m}, 2 \mathrm{H}), 8.07(\mathrm{~d}, J=8.8 \mathrm{~Hz}, 1 \mathrm{H}), 7.95(\mathrm{dd}$,<smiles>[R]c1ccc(Nc2ccc([R])cc2)cc1</smiles>
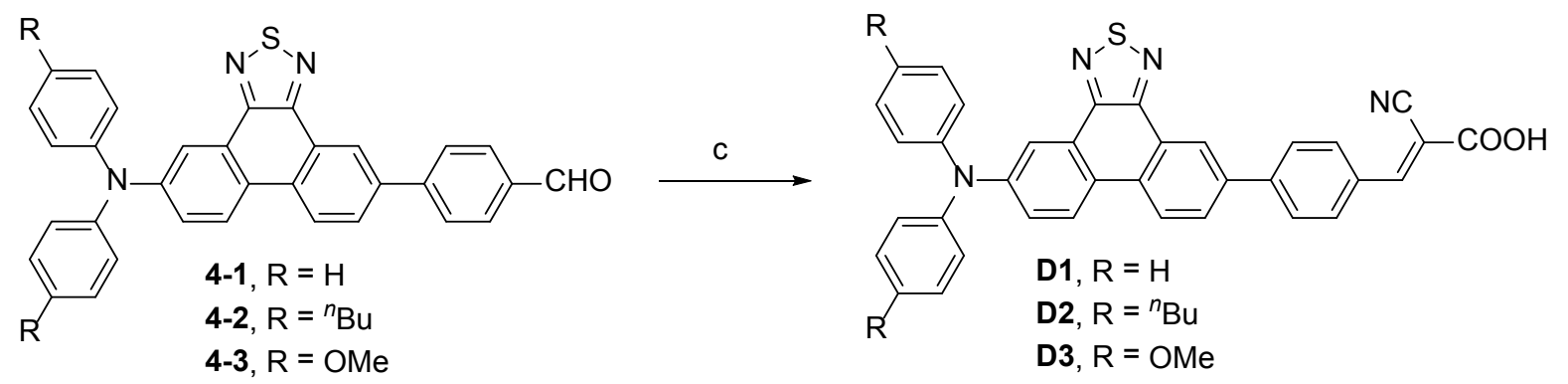

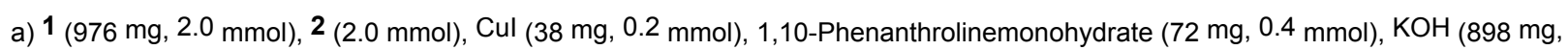
$16.0 \mathrm{mmol})$, toluene $\left.(20 \mathrm{~mL}), 120^{\circ} \mathrm{C}, 24 \mathrm{~h}, \mathrm{~N}_{2} \cdot \mathrm{b}\right){ }^{3}(2.0 \mathrm{mmol}), 4$-bromobenzaldehyde $(450 \mathrm{mg}, 3.0 \mathrm{mmol}), \mathrm{Pd}(\mathrm{PPh} 3) 4(116 \mathrm{mg}$, $\left.0.1 \mathrm{mmol}), \mathrm{K}_{2} \mathrm{CO}_{3}(2.0 \mathrm{M}, 2.0 \mathrm{~mL}), \mathrm{THF}(10 \mathrm{~mL}), 80{ }^{\circ} \mathrm{C}, 24 \mathrm{~h}, \mathrm{~N}_{2} \cdot \mathrm{c}\right) 4(1.0 \mathrm{mmol})$, cyanoacetic acid $(94 \mathrm{mg}, 1.1 \mathrm{mmol})$, ammonium acetate $(20 \mathrm{mg}, 0.25 \mathrm{mmol})$, acetic acid $(5.0 \mathrm{~mL}), 120^{\circ} \mathrm{C}, 5 \mathrm{~h}$.

Scheme 1. The synthetic routes of D1, D2, and D3. 
$J=8.8,2.0 \mathrm{~Hz}, 1 \mathrm{H}), 7.38(\mathrm{dd}, J=8.8,2.4 \mathrm{~Hz}, 1 \mathrm{H}), 7.15-7.10(\mathrm{~m}, 8 \mathrm{H}), 2.61(\mathrm{t}, J=$ $8.0 \mathrm{~Hz}, 4 \mathrm{H}), 1.67-1.59(\mathrm{~m}, 4 \mathrm{H}), 1.45-1.35(\mathrm{~m}, 4 \mathrm{H}), 0.96(\mathrm{t}, J=7.3 \mathrm{~Hz}, 6 \mathrm{H}) .{ }^{13} \mathrm{C}$ NMR (100 MHz, $\left.\mathrm{CDCl}_{3}\right) \delta 153.1,152.2,148.7,144.7,138.9,138.1,134.6,131.0$, 129.7, 127.3, 126.5, 125.4, 124.5, 124.3, 124.0, 123.6, 116.4, 92.1, 35.3, 33.8, 22.7, 14.2. HRMS (EI, m/z): calcd. for $\mathrm{C}_{34} \mathrm{H}_{32} \mathrm{~N}_{3} \mathrm{SI}, 641.1362$ [M]; found, 641.1356 .

3-3, (yellow solid, $49 \%$ yield), $\mathrm{mp} 207^{\circ} \mathrm{C}-208^{\circ} \mathrm{C} .{ }^{1} \mathrm{H} \mathrm{NMR}\left(400 \mathrm{MHz}, \mathrm{CDCl}_{3}\right.$ ) $\delta 8.98(\mathrm{~d}, J=1.6 \mathrm{~Hz}, 1 \mathrm{H}), 8.19(\mathrm{~d}, J=9.2 \mathrm{~Hz}, 1 \mathrm{H}), 8.11(\mathrm{~d}, J=2.8 \mathrm{~Hz}, 1 \mathrm{H}), 8.04$ $(\mathrm{d}, J=8.8 \mathrm{~Hz}, 1 \mathrm{H}), 7.93(\mathrm{dd}, J=8.4,1.6 \mathrm{~Hz}, 1 \mathrm{H}), 7.29(\mathrm{dd}, J=9.2,2.8 \mathrm{~Hz}, 1 \mathrm{H})$, 7.19 - $7.15(\mathrm{~m}, 4 \mathrm{H}), 6.92-6.88(\mathrm{~m}, 4 \mathrm{H}), 3.85(\mathrm{~s}, 6 \mathrm{H}) .{ }^{13} \mathrm{C}$ NMR $(100 \mathrm{MHz}$, $\left.\mathrm{CDCl}_{3}\right) \delta 156.7,150.3,124.5,120.2,116.3,108.6,106.9,104.4,95.2,94.5,94.0$, 90.1, 87.9, 82.9, 79.6, 23.0. HRMS (EI, m/z): calcd. for $\mathrm{C}_{28} \mathrm{H}_{20} \mathrm{~N}_{3} \mathrm{O}_{2} \mathrm{SI}, 589.0321$ [M]; found, 589.0314 .

4-1, (yellow solid, $80 \%$ yield), mp $173^{\circ} \mathrm{C}-174^{\circ} \mathrm{C} .{ }^{1} \mathrm{H}$ NMR $(400 \mathrm{MHz}$, $d 6$-DMSO) $\delta 10.10(\mathrm{~s}, 1 \mathrm{H}), 8.85(\mathrm{~s}, 1 \mathrm{H}), 8.70(\mathrm{~d}, J=8.8 \mathrm{~Hz}, 1 \mathrm{H}), 8.65(\mathrm{~d}, J=9.2$ $\mathrm{Hz}, 1 \mathrm{H}), 8.18(\mathrm{dd}, J=8.6,1.9 \mathrm{~Hz}, 1 \mathrm{H}), 8.12(\mathrm{~d}, J=8.4 \mathrm{~Hz}, 2 \mathrm{H}), 8.06(\mathrm{~d}, J=8.4$ $\mathrm{Hz}, 2 \mathrm{H}), 8.02(\mathrm{~d}, J=5.6 \mathrm{~Hz}, 2 \mathrm{H}), 7.45-7.41(\mathrm{~m}, 4 \mathrm{H}), 7.23(\mathrm{~d}, J=8.3 \mathrm{~Hz}, 6 \mathrm{H})$. ${ }^{13} \mathrm{C}$ NMR (100 MHz, d6-DMSO) $\delta 193.3,153.0,148.4,146.8,145.0,144.9,136.3$, $135.9,130.8,130.7,130.5,129.2,128.4,127.9,126.4,126.2,126.0,125.1,124.6$, 123.9, 123.6, 115.7. HRMS (EI, m/z): calcd. for $\mathrm{C}_{33} \mathrm{H}_{21} \mathrm{~N}_{3} \mathrm{OS}, 507.1405[\mathrm{M}]^{+}$; found, 507.1414 .

4-2, (yellow solid, $92 \%$ yield), $\mathrm{mp} 134^{\circ} \mathrm{C}-135^{\circ} \mathrm{C} .{ }^{1} \mathrm{H}$ NMR (400 $\mathrm{MHz}, \mathrm{CDCl}_{3}$ ) $\delta 10.10(\mathrm{~s}, 1 \mathrm{H}), 8.96(\mathrm{~s}, 1 \mathrm{H}), 8.46(\mathrm{~d}, J=8.4 \mathrm{~Hz}, 1 \mathrm{H}), 8.33-8.29(\mathrm{~m}, 2 \mathrm{H}), 8.04-$ $7.97(\mathrm{~m}, 5 \mathrm{H}), 7.41(\mathrm{dd}, J=8.8,2.0 \mathrm{~Hz}, 1 \mathrm{H}), 7.17-7.11(\mathrm{~m}, 8 \mathrm{H}), 2.62(\mathrm{t}, J=8.0$ $\mathrm{Hz}, 4 \mathrm{H}), 1.67-1.60(\mathrm{~m}, 4 \mathrm{H}), 1.45-1.36(\mathrm{~m}, 4 \mathrm{H}), 0.97(\mathrm{t}, J=7.3 \mathrm{~Hz}, 6 \mathrm{H}) .{ }^{13} \mathrm{C}$ NMR $\left(100 \mathrm{MHz}, \mathrm{CDCl}_{3}\right) \delta 192.1,153.6,153.5,148.7,146.0,144.7,139.0,137.7$, $135.5,131.9,130.6,129.7,128.4,127.7,127.5,125.4,124.7,124.5,124.3,123.7$, 116.4, 35.3, 33.8, 22.7, 14.2. HRMS (EI, m/z): calcd. for $\mathrm{C}_{41} \mathrm{H}_{37} \mathrm{~N}_{3} \mathrm{OS}, 619.2657$ $[\mathrm{M}]^{+}$; found, 619.2653 .

4-3, (yellow solid, $80 \%$ yield), $\mathrm{mp} 107^{\circ} \mathrm{C}-108^{\circ} \mathrm{C} .{ }^{1} \mathrm{H}$ NMR $(400 \mathrm{MHz}, \mathrm{CDCl} 3)$ $\delta 10.01(\mathrm{~s}, 1 \mathrm{H}), 8.95(\mathrm{~s}, 1 \mathrm{H}), 8.44(\mathrm{~d}, J=8.8 \mathrm{~Hz}, 1 \mathrm{H}), 8.29(\mathrm{~d}, J=9.2 \mathrm{~Hz}, 1 \mathrm{H})$, $8.16(\mathrm{~d}, J=2.8 \mathrm{~Hz}, 1 \mathrm{H}), 8.03-7.95(\mathrm{~m}, 5 \mathrm{H}), 7.34(\mathrm{dd}, J=8.8,2.8 \mathrm{~Hz}, 1 \mathrm{H}), 7.21-$ $7.17(\mathrm{~m}, 4 \mathrm{H}), 6.93-6.89(\mathrm{~m}, 4 \mathrm{H}), 3.84(\mathrm{~s}, 6 \mathrm{H}) .{ }^{13} \mathrm{C}$ NMR $\left(100 \mathrm{MHz}, \mathrm{CDCl}_{3}\right) \delta$ $192.0,156.7,153.6,153.5,149.1,146.0,140.1,137.4,135.4,131.9,130.5,128.3$, $127.6,127.4,125.3,124.7,124.5,123.6,123.4,121.8,115.1,114.2,29.9$. HRMS (EI, m/z): calcd. for $\mathrm{C}_{35} \mathrm{H}_{25} \mathrm{~N}_{3} \mathrm{O}_{3} \mathrm{~S}, 567.1617$ [M] ${ }^{+}$; found, 567.1619.

$\mathrm{D} 1$, (red solid, $68 \%$ yield), mp $214^{\circ} \mathrm{C}-215^{\circ} \mathrm{C} .{ }^{1} \mathrm{H}$ NMR (400 MHz, d6-DMSO) $\delta 8.73(\mathrm{~s}, 1 \mathrm{H}), 8.57(\mathrm{~d}, J=9.2 \mathrm{~Hz}, 1 \mathrm{H}), 8.53(\mathrm{~d}, J=9.2 \mathrm{~Hz}, 1 \mathrm{H}), 8.32(\mathrm{~s}, 1 \mathrm{H}), 8.14$ $(\mathrm{d}, J=8.4 \mathrm{~Hz}, 2 \mathrm{H}), 8.02(\mathrm{~d}, J=8.4 \mathrm{~Hz}, 1 \mathrm{H}), 8.02(\mathrm{~d}, J=8.4 \mathrm{~Hz}, 2 \mathrm{H}), 7.94(\mathrm{~d}, J=$ $2.4 \mathrm{~Hz}, 1 \mathrm{H}), 7.44-7.40(\mathrm{~m}, 4 \mathrm{H}), 7.29$ (dd, $J=8.8,2.4 \mathrm{~Hz}, 1 \mathrm{H}), 7.23-7.21(\mathrm{~m}$, $6 \mathrm{H}) .{ }^{13} \mathrm{C}$ NMR (100 MHz, $d 6$-DMSO) $\delta 163.7,153.2,152.9,152.5,148.1,146.8$, 143.0, 137.4, 131.7, 131.5, 131.4, 130.6, 130.4, 128.8, 127.7, 126.9, 126.1, 126.0, 125.1, 125.0, 124.7, 124.5, 123.5, 123.3, 117.4, 115.5. HRMS (ESI, m/z): calcd. for $\mathrm{C}_{36} \mathrm{H}_{22} \mathrm{~N}_{4} \mathrm{O}_{2} \mathrm{~S}, 574.1463[\mathrm{M}]^{+}$; found, 574.1459. 
D2, (red solid, $76 \%$ yield), $\mathrm{mp} 131^{\circ} \mathrm{C}-132^{\circ} \mathrm{C} .{ }^{1} \mathrm{H}$ NMR (400 $\mathrm{MHz}$, $d 6$-DMSO ) $\delta 8.77(\mathrm{~s}, 1 \mathrm{H}), 8.57(\mathrm{~d}, J=8.8 \mathrm{~Hz}, 1 \mathrm{H}), 8.50(\mathrm{~d}, J=9.2 \mathrm{~Hz}, 1 \mathrm{H}), 8.37$ $(\mathrm{s}, 1 \mathrm{H}), 8.18(\mathrm{~d}, J=8.4 \mathrm{~Hz}, 2 \mathrm{H}), 8.11(\mathrm{~d}, J=8.4 \mathrm{~Hz}, 1 \mathrm{H}), 8.06(\mathrm{~d}, J=8.3 \mathrm{~Hz}, 2 \mathrm{H})$, $7.89(\mathrm{~d}, J=2.5 \mathrm{~Hz}, 1 \mathrm{H}), 7.23-7.10(\mathrm{~m}, 9 \mathrm{H}) .{ }^{13} \mathrm{C} \mathrm{NMR}(100 \mathrm{MHz}, d 6-\mathrm{DMSO}) \delta$ $163.4,152.8,152.3,152.0,147.3,143.7,142.8,138.4,135.9,131.2,130.6,129.3$, $126.8,126.0,125.4,124.0,122.8,116.3,113.4,103.5,34.4,33.0,21.9,13.7$. HRMS (ESI, m/z): calcd. for $\mathrm{C}_{44} \mathrm{H}_{38} \mathrm{~N}_{4} \mathrm{O}_{2} \mathrm{~S}, 686.2715[\mathrm{M}]^{+}$; found, 686.2710.

D3, (red solid, $57 \%$ yield), $\mathrm{mp} 190^{\circ} \mathrm{C}-191^{\circ} \mathrm{C} .{ }^{1} \mathrm{H}$ NMR (400 MHz, d6-DMSO ) $\delta 8.62(\mathrm{~s}, 1 \mathrm{H}), 8.47(\mathrm{~s}, 1 \mathrm{H}), 8.39(\mathrm{~s}, 1 \mathrm{H}), 8.05-7.83(\mathrm{~m}, 6 \mathrm{H}), 7.72$ (s, $1 \mathrm{H}), 7.20(\mathrm{~d}, J=8.4 \mathrm{~Hz}, 4 \mathrm{H}), 7.09(\mathrm{~d}, J=8.8 \mathrm{~Hz}, 1 \mathrm{H}), 7.00(\mathrm{~d}, J=8.8 \mathrm{~Hz}, 4 \mathrm{H})$, 3.80 (s, 6H). ${ }^{13} \mathrm{C}$ NMR (100 MHz, d6-DMSO) $\delta 119.1,115.6,114.7,111.6,102.4$, 100.6, 97.1, 93.6, 89.7, 88.8, 86.8, 86.7, 85.6, 84.2, 77.5, 76.6, 18.0. HRMS (ESI, $\mathrm{m} / \mathrm{z}$ ): calcd. for $\mathrm{C}_{38} \mathrm{H}_{26} \mathrm{~N}_{4} \mathrm{O}_{4} \mathrm{~S}, 634.1675[\mathrm{M}]^{+}$; found, 634.1667 .

\subsection{Absorption Properties of the Dyes in Solution}

UV-vis absorption spectra of three dyes in $\mathrm{CH}_{2} \mathrm{Cl}_{2} / \mathrm{CH}_{3} \mathrm{OH}(10 / 1)$ solution are depicted in Figure 2. All dyes in solutions gave two distinct absorption bands: one relatively weak band in the near-ultraviolet region ( $300 \mathrm{~nm}$ to $340 \mathrm{~nm}$ ) that corresponds to the $\pi-\pi^{*}$ electron transition and another with a strong absorption in the visible region ( $370 \mathrm{~nm}$ to $450 \mathrm{~nm}$ ). The bands can be assigned to an intramolecular charge transfer between the triarylamine donating unit and the cyanoacrylic acid anchoring moiety, thereby producing an efficient charge-separated state. The absorption data of D1 $\left(384 \mathrm{~nm}, 26,960 \mathrm{M}^{-1} \cdot \mathrm{cm}^{-1}\right)$, D2 (395 nm, $\left.27007 \mathrm{M}^{-1} \cdot \mathrm{cm}^{-1}\right)$ and D3 (397 nm, $\left.25625 \mathrm{M}^{-1} \cdot \mathrm{cm}^{-1}\right)$ are shown in Table 1 .

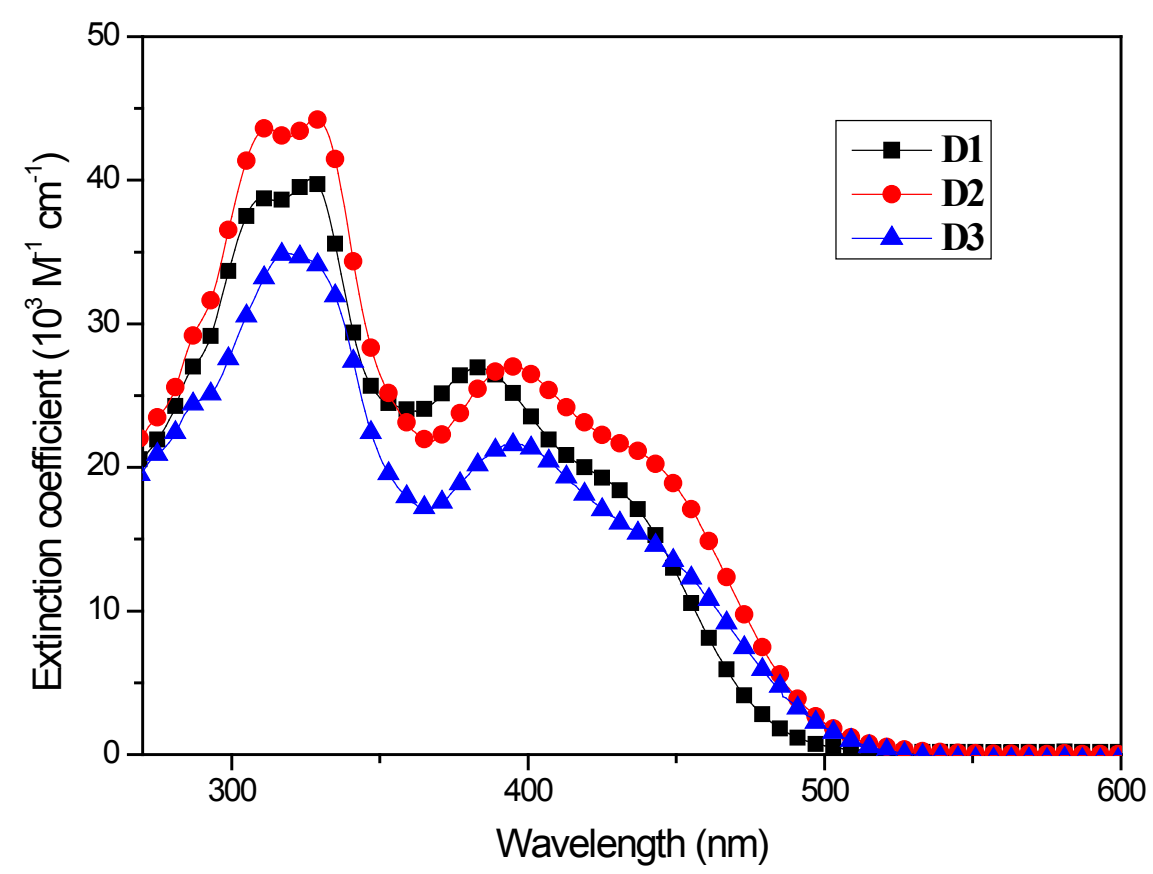

Figure 2. Absorption spectra of D1, D2, and D3 in $\mathrm{CH}_{2} \mathrm{Cl}_{2} / \mathrm{CH}_{3} \mathrm{OH}(10 / 1)$. 
Table 1. Optical and electrochemical properties of D1, D2, and D3 dyes.

\begin{tabular}{|c|c|c|c|c|c|c|}
\hline \multirow[b]{2}{*}{ Dye } & \multicolumn{2}{|c|}{ Absorption $^{\mathrm{a}}$} & \multirow{2}{*}{$\begin{array}{c}\text { Emission }^{\mathrm{a}} \\
\begin{array}{c}\Lambda \max \\
{[\mathrm{nm}]}\end{array}\end{array}$} & \multicolumn{3}{|c|}{ Oxidation potential } \\
\hline & $\begin{array}{l}\Lambda \max \\
{[\mathrm{nm}]}\end{array}$ & $\begin{array}{c}\varepsilon \text { at } \lambda \max \\
{\left[\mathrm{M}^{-1} \cdot \mathrm{cm}^{-1}\right]}\end{array}$ & & $\begin{array}{c}\text { Eox }[\mathrm{V}]^{\mathrm{b}} \\
\text { (versus NHE) }\end{array}$ & $\begin{array}{l}\mathrm{E}_{0-0}[\mathrm{~V}]^{\mathrm{c}} \\
(\mathrm{Abs} / \mathrm{Em})\end{array}$ & $\begin{array}{c}\text { ELUMO [V] } \\
\text { (versus NHE) }\end{array}$ \\
\hline $\mathrm{F} 1$ & 384 & 26960 & 510 & 1.22 & 2.52 & -1.30 \\
\hline $\mathrm{F} 2$ & 395 & 27007 & 523 & 1.14 & 2.43 & -1.29 \\
\hline F3 & 397 & 21625 & 527 & 0.94 & 2.44 & -1.50 \\
\hline
\end{tabular}

${ }^{a}$ Absorption and emission spectra were measured in $\mathrm{CH}_{2} \mathrm{Cl}_{2} / \mathrm{CH}_{3} \mathrm{OH}$ (10/1), with a concentration of $1.0 \times$ $10^{-5} \mathrm{M}$ at room temperature. ${ }^{b}$ The oxidation potential of the dyes was measured under the following conditions: working electrode, Pt; electrolyte, $0.1 \mathrm{M}$ tetrabutylammonium hexafluorophosphate, $n-\mathrm{Bu}_{4} \mathrm{NPF}_{6}$ in THF; scan rate, $0.1 \mathrm{~V} / \mathrm{s}$. Potentials measured vs $\mathrm{Fe}^{+} / \mathrm{Fe}$ were converted to $\mathrm{NHE}$ by addition of $+0.63 \mathrm{~V}$. ${ }^{\circ}$ The $\mathrm{E}_{0-0}$ energies were estimated from the intercept of the normalized absorption and emission spectra.

\subsection{Electrochemical Properties}

The redox behavior of these dyes was studied by cyclic voltammetry (Figure 3 ). The cyclic voltammograms of D1, D2, and D3 were measured in a solution of $0.1^{\circ} \mathrm{M} n-\mathrm{Bu}_{4} \mathrm{NPF}_{6}$ in $\mathrm{CH}_{2} \mathrm{Cl}_{2} / \mathrm{CH}_{3} \mathrm{OH}(10 / 1)$. A three-electrode cell containing a $\mathrm{Pt}$-coil working electrode, a $\mathrm{Pt}$ wire counter electrode, and a $\mathrm{Ag} / \mathrm{AgCl}$ reference electrode was employed. The ferrocene/ferricenium redox couple was used as an internal reference. The examined highest occupied molecular orbital (HOMO) levels and the lowest unoccupied molecular orbital (LUMO) levels were collected, as shown in Table 1 . HOMO values ( $0.94 \mathrm{~V}$ to $1.22 \mathrm{~V}$ vs. NHE) were more positive than the $\mathrm{I}^{-} / \mathrm{I}^{3-}$ redox couple $(0.4 \mathrm{~V}$ vs. NHE), thus suggesting that the oxidized dyes can thermodynamically accept electrons from $\mathrm{I}^{-}$ion in iodide/triiodide electrolyte for regeneration. Electron injection from the excited sensitizers to the conduction band of $\mathrm{TiO}_{2}$ should be energetically favorable because of the more negative LUMO values $(-1.29 \mathrm{~V}$ to $-1.50 \mathrm{~V}$ vs. NHE) compared with the conduction band edge energy level of the $\mathrm{TiO}_{2}$ electrode (at approximately $-0.5 \mathrm{~V}$ vs. NHE). Table 1 shows that the introduction of the methoyl and methyl groups on arylamine can change the HOMO-LUMO energy gaps of the dyes narrowly. These results clearly demonstrate that dyes D1, D2, and D3 are potentially efficient dyes for DSSCs.

\subsection{Photovoltaic Performance}

The action spectrum, or the IPCE as a function of wavelength, was measured to evaluate the photoresponse of the photoelectrode in the whole spectral region. D1, D2, and D3 sensitizers were used to manufacture solar cell devices. Figure 4 shows the IPCE obtained with $0.06 \mathrm{M} \mathrm{LiI}, 0.03 \mathrm{M} \mathrm{I}_{2}, 0.1 \mathrm{M}$ guanidinium thiocyanate, $0.6 \mathrm{M}$ PMII, and $0.5 \mathrm{M}$ tert-butyl-pyridine in acetonitrile as redox electrolyte. The three dyes can efficiently convert visible light into photocurrent in the region of $300 \mathrm{~nm}$ to $600 \mathrm{~nm}$. A solar cell based on D3 showed the highest IPCE value of $75 \%$ at $491 \mathrm{~nm}$. In addition, the cell exhibited a broad IPCE spectrum with IPCE values (>70\%) ranging from $390 \mathrm{~nm}$ to $520 \mathrm{~nm}$. The IPCE spectra of D1 and D2 were slightly low, with a maximum IPCE of $68 \%$ at $450 \mathrm{~nm}$ and $69 \%$ at $445 \mathrm{~nm}$, respectively. 


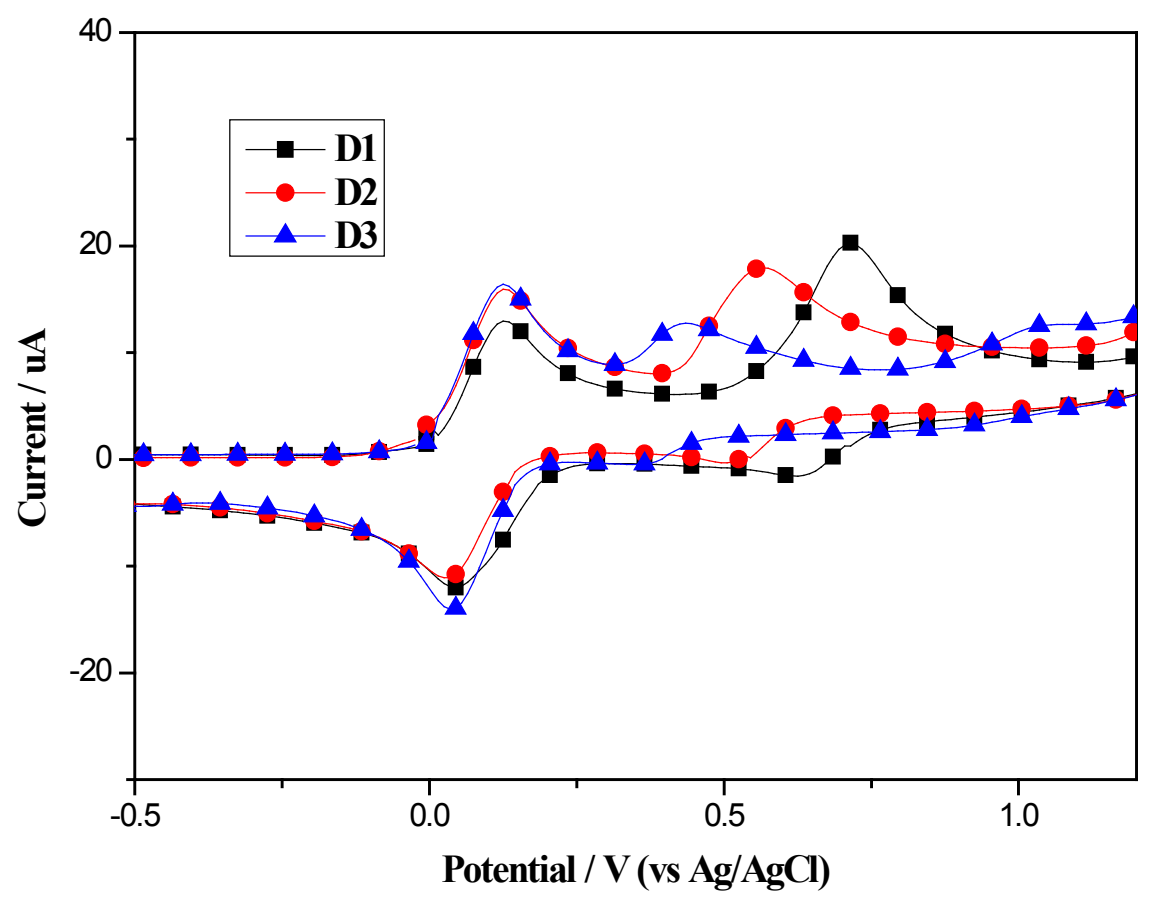

Figure 3. Cyclic voltammograms of D1, D2, and D3.

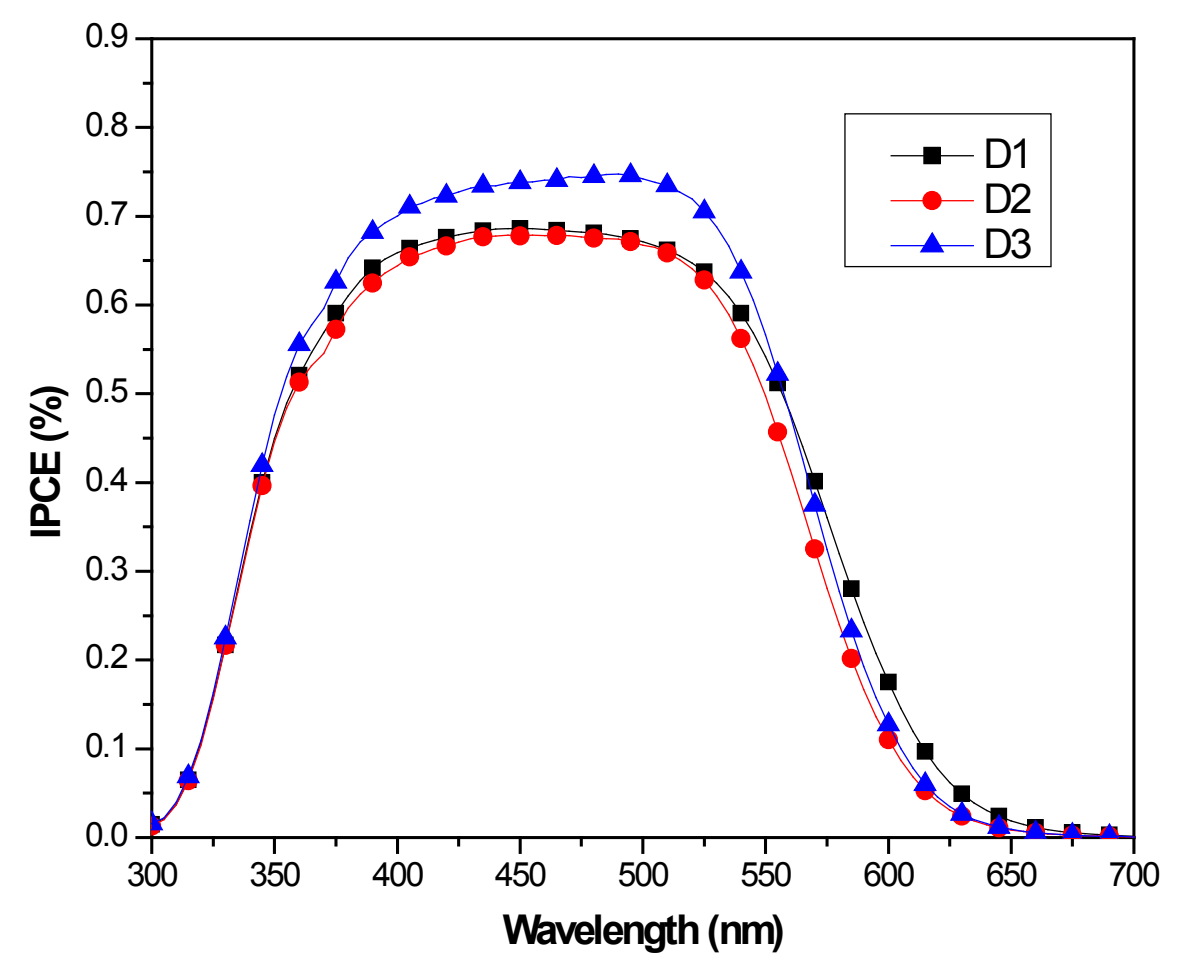

Figure 4. IPCE spectra f based on D1, D2, and D3.

Figure 5 shows the $J-V$ curves of the DSSCs based on the D1, D2, and D3 dyes under standard global AM 1.5 G solar irradiation, and the results are provided in Table 2. The DSSCs based on the D3 dye showed a short-circuit photocurrent density of $9.70 \mathrm{~mA} / \mathrm{cm}^{-2}$, an open-circuit voltage of $0.77 \mathrm{~V}$, and a fill 


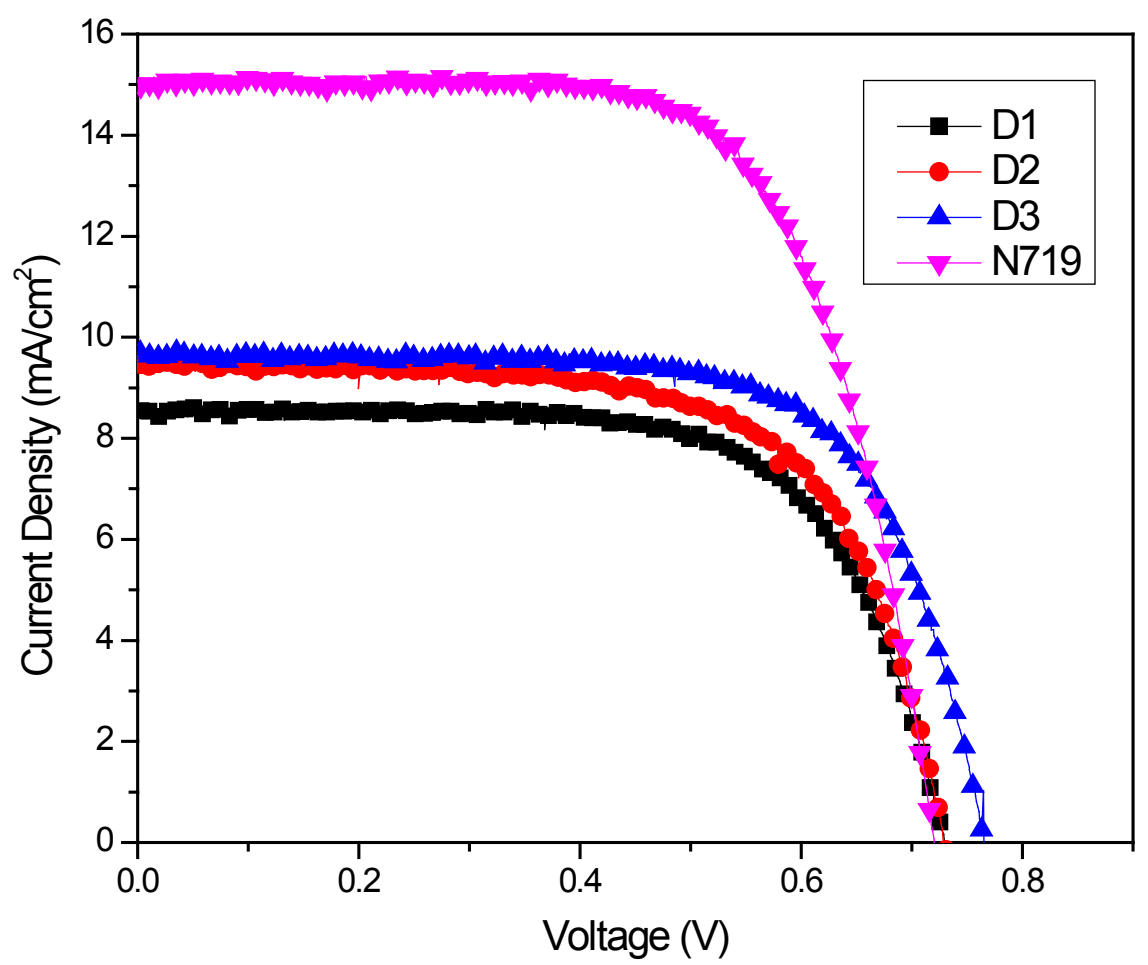

Figure 5. $J-V$ curves based on based on D1, D2, D3, and N719.

Table 2. Photovoltaic Performance based on D1, D2, D3, and N719.

\begin{tabular}{ccccc}
\hline Dye & $\mathrm{Jsc} / \mathrm{mA} \mathrm{cm}^{-2}$ & Voc/mV & ff & $\eta / \%$ \\
\hline D1 & 9.41 & 0.73 & 0.67 & 4.60 \\
D2 & 8.52 & 0.73 & 0.69 & 4.29 \\
D3 & 9.70 & 0.77 & 0.70 & 5.23 \\
N719 & 15.04 & 0.72 & 0.69 & 7.47 \\
\hline
\end{tabular}

The DSSCs had an active area of $\sim 0.36 \mathrm{~cm}^{2}$ and used an electrolyte composed of $0.06 \mathrm{M} \mathrm{LiI}, 0.03 \mathrm{M} \mathrm{I}_{2}, 0.1 \mathrm{M}$ guanidinium thiocyanate, $0.6 \mathrm{M}$ 1-propyl-3-methylimidazolium iodide (PMII), and $0.5 \mathrm{M} t$-butyl-pyridine in acetonitrile.

factor of 0.70 , thereby yielding an overall conversion efficiency $(\eta)$ of $5.23 \%$. Under the same measurement conditions, cells that were sensitized with D1 and D2 exhibit Jsc of 9.41 and $8.52 \mathrm{~mA} / \mathrm{cm}^{-2}$, Voc of 0.73 , and $0.73 \mathrm{~V}$, and ff of 0.67 and 0.69 , corresponding to $\eta$ of $4.60 \%$ and $4.29 \%$, respectively. By comparison, the N719-sensitized $\mathrm{TiO}_{2}$ solar cell showed an efficiency of 7.47\%, with a J SC of $15.04 \mathrm{~mA} / \mathrm{cm}^{-2}$, a $V o c$ of $0.72 \mathrm{~V}$, and a ff of 0.69 . The conversion efficiency of D3 reached $70 \%$ of the $\mathrm{N} 719$ cell efficiency.

\section{Conclusion}

In summary, three new organic dyes (D1, D2, and D3) containing a phenanthrothiadiazole unit as a $\pi$-conjugated system, a triarylamine as an electron donor, and a cyanoacrylic acid moiety as an electron acceptor were designed and synthesized for DSSCs. DSSCs based on D3 produced a photon-to-current conver- 
sion efficiency of $5.23 \%\left(\mathrm{Jc}=9.70 \mathrm{~mA} / \mathrm{cm}^{-2}, V o c=0.77 \mathrm{~V}, \mathrm{ff}=0.70\right)$ under 100 $\mathrm{mW} / \mathrm{cm}^{2}$ simulated AM $1.5 \mathrm{G}$ solar irradiation. Compared with the D1 and D2 based cells, D3 showed higher Jsc values, reflecting its better sunlight-harvesting ability. The application of phenanthrothiadiazole unit in organic photovoltaic solar cell is ongoing in our laboratory.

\section{Acknowledgements}

We are grateful to the National Natural Science Foundation of China (Nos. 21572028 and 21372035) for their financial support. This work was also supported by Liaoning Natural Science Foundation of China (201602181) and the Outstanding Young Scholars Development Growth Plan of universities in Liaoning Province (LJQ2015027).

\section{References}

[1] Grätzel, M. (2003) Dye-Sensitized Solar Cells. Photochem. Photobiol. C, 4, 145-153. https://doi.org/10.1016/S1389-5567(03)00026-1

[2] Mishra, A., Fuscher, M.R. and Bäuerle, P. (2009) Metal-Free Organic Dyes for Dye-Sensitized Solar Cells: From Structure: Property Relationships to Design Rules. Angew. Chem. Int. Ed, 48, 2474-2499. https://doi.org/10.1002/anie.200804709

[3] Liang, M. and Chen, J. (2013) Arylamine Organic Dyes for Dye-Sensitized Solar Cells. Chem. Soc. Rev, 42, 3453-3488. https://doi.org/10.1039/c3cs35372a

[4] Qin, C.J., Numata, Y., Zhang, S.F., Islam, A., Yang, X.D., Sodeyama, K., Tateyama, Y. and Han, L.Y. (2013) A Near-Infrared Cis-Configured Squaraine Co-Sensitizer for High-Efficiency Dye-Sensitized Solar Cells. Adv. Funct. Mater, 23, 3782-3789. https://doi.org/10.1002/adfm.201203384

[5] Wu, Z.S., An, Z.W., Chen, X.B. and Chen, P. (2013) Cyclic Thiourea/Urea Functionalized Triphenylamine-Based Dyes for High-Performance Dye-Sensitized Solar Cells. Org. Lett, 15, 1456-1459. https://doi.org/10.1021/ol4001685

[6] Liu, W.H., Wu, I.C., Lai, C.H., Chou, P.T., Li, Y.T., Chen, C.L., Hsu, Y.Y. and Chi, Y. (2008) Simple Organic Molecules Bearing a 3,4-Ethylenedioxythiophene Linker for Efficient Dye-Sensitized Solar Cells. Chem. Commun, 41, 5152-5154. https://doi.org/10.1039/B808535H

[7] Shen, P., Liu, Y.J., Huang, X.W., Zhao, B., Xiang, N., Fei, J.J., Liu, L.M., Wang, X.Y., Huang, H. and Tan, S.T. (2009) Efficient Triphenylamine Dyes for Solar Cells: Effects of Alkyl-Substituents and $\pi$-Conjugated Thiophene Unit. Dyes Pigm, 83, 187-197. https://doi.org/10.1016/j.dyepig.2009.04.005

[8] Dentani, T., Kubota, Y., Funabiki, K., Jin, J., Yoshida, T., Minoura, H., Miura, H. and Matsui, M. (2009) Novel Thiophene-Conjugated Indoline Dyes for Zinc Oxide Solar Cells. New J. Chem, 33, 93-101. https://doi.org/10.1039/B808959K

[9] Thomas, K.R.J., Hsu, Y.C., Lin, J.T., Lee, K.M., Ho, K.C., Lai, C.H., Cheng, Y.M. and Chou, P.T. (2008) 2,3-Disubstituted Thiophene-Based Organic Dyes for Solar Cells. Chem. Mater, 20, 1830-1840. https://doi.org/10.1021/cm702631r

[10] Hwang, S., Lee, J.H., Park, C., Lee, H., Kim, C., Park, C., Lee, M.H., Lee, W., Park, J., Kim, K., Park, N.G. and Kim, C. (2007) A Highly Efficient Organic Sensitizer for Dye-Sensitized Solar Cells. Chem. Commun, 46, 4887-4889. https://doi.org/10.1039/b709859f

[11] Chen, K.F., Hsu, Y.C., Wu, Q.Y., Yeh, M.C.P. and Sun, S.S. (2009) Structurally Sim- 
ple Dipolar Organic Dyes Featuring 1,3-Cyclohexadiene Conjugated Unit for Dye-Sensitized Solar Cells.. Org. Lett, 11, 377-380. https://doi.org/10.1021/ol802630x

[12] Liang, M., Xu, W., Cai, F.S., Chen, P.Q., Peng, B., Chen, J., Li, Z.M. and Chen, J. (2007) New Triphenylamine-Based Organic Dyes for Efficient Dye-Sensitized Solar Cells. J. Phys. Chem. C, 111, 4465-4472. https://doi.org/10.1021/jp067930a

[13] Kim, C., Choi, H., Kim, S., Baik, C., Song, K., Kang, M.S., Kang, S.O. and Ko, J. (2008) Molecular Engineering of Organic Sensitizers Containing $p$-Phenylene Vinylene Unit for Dye-Sensitized Solar Cells. J. Org. Chem, 73, 7072-7079. https://doi.org/10.1021/jo8005182

[14] Xu, W., Peng, B., Chen, J., Liang, M. and Cai, F.S. (2008) New Triphenylamine-Based Dyes for Dye-Sensitized Solar Cells. J. Phys. Chem. C, 112, 874-880. https://doi.org/10.1021\%2Fjp076992d

[15] Cai, N., Zhang, J., Xu, M. and Wang, P. (2013) Improving the Photovoltage of Dithienopyrrole Dye-Sensitized Solar Cells via Attaching the Bulky Bis(Octyloxy)Biphenyl Moiety to the Conjugated $\pi$-Linker. Adv. Funct. Mater, 23, 3539-3547. https://doi.org/10.1002/adfm.201203348

[16] Hara, K., Wang, Z.S., Sato, T., Furube, A., Katoh, R., Sugihara, H., Dan-oh, Y., Kasada, C., Shinpo, A. and Suga, S. (2005) Oligothiophene-Containing Coumarin Dyes for Efficient Dye-Sensitized Solar Cells. J. Phys. Chem. B, 109, 15476-15482. https://doi.org/10.1021/jp0518557

[17] Li, G., Jiang, K.J., Li, Y.F., Li, S.L. and Yang, L.M. (2008) Efficient Structural Modification of Triphenylamine-Based Organic Dyes for Dye-Sensitized Solar Cells. J. Phys. Chem. C, 112, 11591-11599. https://doi.org/10.1021/jp802436v

[18] Zhang, G.L., Bai, Y., Li, R.Z., Shi, D., Wenger, S., Zakeeruddin, S.M., Grätzelb, M. and Wang, P. (2009) Employ a Bisthienothiophene Linker to Construct an Organic Chromophore for Efficient and Stable Dye-Sensitized Solar Cells. Energy Environ. Sci, 2, 92-95. https://doi.org/10.1039/B817990E

[19] Qin, H., Wenger, S., Xu, M.F., Gao, F.F., Jing, X.Y., Wang, P., Zakeeruddin, S.M. and Grätzel, M. (2008) An Organic Sensitizer with a Fused Dithienothiophene Unit for Efficient and Stable Dye-Sensitized Solar Cells. J. Am. Chem. Soc, 130, 9202-9203. https://doi.org/10.1021/ja8024438

[20] Choi, H., Baik, C., Kang, S.O., Ko, J., Kang, M.S., Nazeeruddin, M.K. and Grätzel, M. (2008) Highly Efficient and Thermally Stable Organic Sensitizers for Solvent-Free Dye-Sensitized Solar Cells. Angew Chem. Int. Ed, 47, 327-330. https://doi.org/10.1002/anie.200703852

[21] Choi, H., Lee, J.K., Song, K. and Kang, S.O. (2007) Novel Organic Dyes Containing Bis-Dimethylfluorenyl Amino Benzo[b]Thiophene for Highly Efficient Dye-Sensitized Solar Cells. Tetrahedron, 63, 3115-3121. https://doi.org/10.1016/j.tet.2007.02.018

[22] Kim, S.H., Kim, H.W., Sakong, C., Namgoong, J., Park, S.W., Ko, M.J., Lee, C.H., Lee, W.I. and Kim, J.P. (2011) Effect of Five-Membered Heteroaromatic Linkers to the Performance of Phenothiazine-Based Dye-Sensitized Solar Cells. Org. Lett, 13, 5784-5787. https://doi.org/10.1021/ol2023517

[23] Akhtaruzzaman, M., Seya, Y., Asao, N., Islam, A., EI-Shafei, A., Han, L.Y. and Yamamoto, Y. (2012) Donor-Acceptor Dyes Incorporating a Stable Dibenzosilole $\pi$-Conjugated Spacer for Dye-Sensitized Solar Cells. J. Mater. Chem, 22, 10771-10778. https://doi.org/10.1039/c2jm30978e 